PUBLIC HEALTH RESEARCH

\title{
Factors Associated with Asymptomatic COVID-19 Patients in Petaling District, Selangor, Malaysia
}

\author{
Lim Kuang Kuay, ${ }^{1 *}$ Ainul Nadziha Mohd Hanafiah, ${ }^{2}$ Lee Soo Cheng, ${ }^{3}$ Chan Ying Ying, ${ }^{1}$ Mohd Shaiful Azlan \\ Kassim, ${ }^{1}$ Chong Zhuo Lin, ${ }^{1}$ Roslinda Abu Sapian, ${ }^{4}$ Nurul Syarbani Eliana Musa, ${ }^{5}$ Ridwan Sanaudi ${ }^{6}$ and \\ Mohamed Paid Yusof \\ ${ }^{1}$ Institute for Public Health, National Institutes of Health, Ministry of Health Malaysia. \\ ${ }^{2}$ Institute for Health Systems Research, National Institutes of Health, Ministry of Health, Malaysia. \\ ${ }^{3}$ Petaling District Health Office, Ministry of Health Malaysia, Malaysia. \\ ${ }^{4}$ Research Grant and Management Unit, National Institutes of Health, Ministry of Health, Malaysia. \\ ${ }^{5}$ Collaboration and Innovation Unit, National Institutes of Health, Ministry of Health, Malaysia. \\ ${ }^{6}$ Sector for Biostatistics and Data Repository, National Institutes of Health, Ministry of Health, Malaysia. \\ *For reprint and all correspondence: Lim Kuang Kuay, Institute for Public Health, Ministry of Health Malaysia, \\ Jalan Setia Murni U13/52, Seksyen U13 Setia Alam, 40170 Shah Alam, Selangor. \\ Email:limkk@moh.gov.my
}

\section{ABSTRACT}

\begin{tabular}{|c|c|}
\hline Introduction & $\begin{array}{l}\text { The rapid spread of the Coronavirus disease } 2019 \text { (COVID-19) worldwide has } \\
\text { led the World Health Organization to declare COVID-19 outbreak as a } \\
\text { pandemic on March } 11,2020 \text {. As the local studies on factors leading to the } \\
\text { absence or presence of clinical illness among the COVID-19 cases are sparse, } \\
\text { the study aims to determine the factors associated with asymptomatic COVID- } \\
19 \text { patients in Petaling District, Selangor, Malaysia. }\end{array}$ \\
\hline Methods & $\begin{array}{l}\text { Data on COVID-19 patients were extracted from the database of confirmed } \\
\text { cases in Petaling District Health Office, Selangor, Malaysia from 3rd February } \\
2020 \text { to 30th April 2020. An asymptomatic laboratory-confirmed case is a } \\
\text { person infected with COVID-19 who does not develop any symptoms. The } \\
\text { study included socio-demographic variables, the detailed information on } \\
\text { clinical manifestations and co-morbidity of the patients. Descriptive and } \\
\text { multiple logistic regression analyses were conducted to determine the factors } \\
\text { associated with asymptomatic patients. }\end{array}$ \\
\hline Results & $\begin{array}{l}\text { The overall COVID- } 19 \text { patients in Petaling District were } 434 \text {. Approximately } \\
70 \%(n=292) \text { of the patients were symptomatic while } 32.7 \%(n=142) \text { were } \\
\text { asymptomatic. Multivple logistic regression analyses revealed that factors } \\
\text { significantly associated with asymptomatic patients were age below } 40 \text { years } \\
\text { old (aOR: } 1.79,95 \% \text { CI } 1.11,2.86) \text {, non-Malaysians (aOR: } 3.22,95 \% \text { CI } 1.44 \text {, } \\
7.19 \text { ) and local cases (aOR: } 2.51,95 \% \text { CI } 1.42,4.42) \text {. Gender, ethnicity, co- } \\
\text { morbidity and township were not significantly associated with asymptomatic } \\
\text { patients. }\end{array}$ \\
\hline Conclusions & $\begin{array}{l}\text { Approximately one-third of COVID- } 19 \text { patients were asymptomatic and the } \\
\text { risk factors identified were younger age, non-Malaysians and local cases. } \\
\text { Rigorous epidemiological investigation is helpful in identifying COVID-19 } \\
\text { cases among these group of people who are asymptomatic. }\end{array}$ \\
\hline Keywords & COVID-19 - Asymptomatic - Pandemic - Malaysia. \\
\hline
\end{tabular}

Article history

Received:7 December 2020

Accepted:7 July 2021

Published: 1 September 2021 


\section{INTRODUCTION}

In late December 2019, a first case of unidentified pneumonia was reported in Wuhan, Hubei, China and thereafter, the number of reported cases with the same clinical characteristics had rapidly increased in Wuhan as well as other parts of the world. ${ }^{1,2}$ The investigation revealed that this unidentified disease was caused by a member of the family of coronaviruses and the investigators had named this unidentified pneumonia disease as novel coronavirus pneumonia. ${ }^{3}$ Later, the World Health Organization (WHO) renamed the disease as coronavirus disease 2019 or COVID-19.4 As of March 3rd 2020, the WHO reported that a total of 67,217 and 13,087 confirmed cases have been detected in the Hubei Province and in other 34 provinces in China, respectively. ${ }^{5}$ Thereafter, the positive cases and deaths increased rapidly with major outbreaks reported in South Korea, Italy, Iran, the United States and more than 50 other countries. ${ }^{6}$ This phenomena had sparked a global alarm, leading an expert to postulate that the morbidity might infect $40-70 \%$ of the global population in the coming years. ${ }^{7}$ The rapid spread of the disease unabated worldwide which may endanger the health of large number of people had lead the WHO to declare COVID-19 as a pandemic on March 11, 2020 and has urged all affected countries to take urgent and aggressive action to control this pandemic. ${ }^{8}$

In COVID-19, some people are more vulnerable to the virus than others, it is capable of putting people of any age into a critical condition. The most common symptoms of this highly contagious virus are fever, dry cough, and tiredness. Other less common symptoms include aches and pains, nasal congestion, headache, conjunctivitis, sore throat, diarrhea, loss of taste or smell. These symptoms are usually mild and the majority of this cases have spontaneously recovered. ${ }^{9}$ However, a few people especially older people, and those with underlying medical problems like high blood pressure, heart and lung problems, diabetes, or cancer, are at a higher risk of developing serious illness such as severe pneumonia, pulmonary oedema, acute respiratory distress syndrome, or multiple organ failure. ${ }^{10}$ According to $\mathrm{Wu}$ et $\mathrm{al},{ }^{11}$ about $80 \%$ of the symptomatic COVID-19 cases will remain mild and relatively well, whereas about $15 \%$ will develop more severe disease and the remaining $5 \%$ may require critical care.

The spread of the virus by symptomatic cases is well documented. ${ }^{8-11}$ However, the virus can also be asymptomatic, causing no noticeable illness in some people and this asymptomatic people are the potential sources of COVID-19 infection to other healthy population due to the viral loads in their respiratory secretions could be as high as those from symptomatic cases. ${ }^{12,13}$ Normally, most asymptomatic infections do not seek medical assistance due to no obvious clinical signs and poor prevention awareness, which contribute to the rapid spread of disease. ${ }^{14}$ There is mixed evidence on the proportion of people that are asymptomatic and a few studies revealed the asymptomatic cases can be as high as $80 \%$ and some of this asymptomatic patients will become symptomatic over the next few days or weeks. ${ }^{15-18}$ Studies on factors leading to the absence or presence of clinical illness among the COVID-19 cases are sparse. In the absence of immunisation and proactive testing strategies, a large portion of the population may remain susceptible to COVID-19 infection.

In view of the above scenario, a comprehensive study is warranted to provide relevant information on the factors associated with asymptomatic COVID-19 cases. The findings of this study may assist the relevant health authorities in disease control and prevention measures. Thus, this study aims to determine the factors associated with asymptomatic COVID-19 patients in Petaling District, Selangor, Malaysia.

\section{METHODS}

This cross-sectional study was conducted from February 2020 to April 2020 in Petaling District Health Office, Selangor, Malaysia. The data was extracted from 3rd February 2020 to 30th April 2020 in the Petaling District Health Office database. A confirmed COVID-19 patient was defined as a positive result of naso-pharyngeal samples using laboratory-based Polymerase chain reaction (PCR) test. A symptomatic COVID-19 patient is a person who has developed symptoms compatible with COVID-19 virus infection. While, an asymptomatic laboratory confirmed patient is a person infected with COVID-19 but does not develop any symptoms. $^{5}$

There were seven socio-demographic variables included in this study; sex (male, female), age $(<40$ years and $\geq 40$ years old), ethnicity (Malays, non-Malay), citizenship (Malaysian, nonMalaysian), transmission (local,imported cases); township (Petaling, Sungai Buloh, Damansara, Bukit Raja). The local cases were defined as the patients who got the COVID-19 infection in the country. While, the imported cases were defined as the patients who contracted the COVID-19 from abroad. Presence of co-morbidity was defined as patients who answered "yes" to having two or more co-morbidities (i.e. diabetes mellitus, hypertension, heart disease, chronic lung disease or chronic kidney disease). In addition, the study also included detailed information on clinical manifestations (i.e. fever, cough, runny nose, sore throat and short of breath). Approval to conduct this study was obtained from the Medical Research and Ethics Committee, Ministry of Health Malaysia (NMRR-20-72054598). Prior to the study, permission to undertake the study was obtained from the Petaling District Health Office, Selangor, Malaysia. All patient 
information was kept confidential and specific identification code was given to each patient to ensure confidentiality and anonymity.

Data were analysed using SPSS version 23.0. The patients' profile data was summarized using descriptive statistics [frequency $(n)$ and percentages $(\%)]$. Bivariable analysis was done to examine associations between independent variables and symptomatic/asymptomatic COVID19 cases. Crude odds ratios (cOR) were used to describe the strength of association between each dependent and independent variable. A multivariable logistic regression model was fitted to determine the factors associated with asymptomatic cases, adjusted for all other covariates. The adjusted OR (aOR) and its corresponding 95\% Confidence Interval (CI), with a p-value of less than 0.05 was considered significant in the logistic regression model.

\section{RESULTS}

As of $30^{\text {th }}$ April 2020, a total of 434 COVID-19 patients were reported in the Petaling District, Selangor, Malaysia. Of these, 292 (67.3\%) were patients with symptoms and the remaining $(n=142$,
$32.7 \%$ ) were asymptomatic. The township of Petaling reported the highest number of patients (n $=127,29.3 \%$ ), while the Bukit Raja reported the lowest number of patients (15.2\%). The majority of the patients were Malaysians $(87.8 \%)$, of Malay ethnicity $(62.9 \%)$, males $(54.1 \%)$, and aged $<40$ years old $(51.6 \%)$. Three quarters of the cases were caused by local transmission $(75.3 \%)$ and most of them had no co-morbidity (88.2\%). Among the symptomatic patients, majority of the patients were Malaysians (94.5\%), of Malay ethnicity (67.5\%), aged $\geq 40$ years old $(53.4 \%)$, and from Petaling township (27.4\%). In addition, more than $70 \%$ of the COVID-19 cases were caused by local transmission and most of them $(86.3 \%)$ had no co-morbidity. Fever was the most common symptom among the patients $(68.2 \%)$, followed by cough $(46.9 \%)$ and sore throat (26.0\%). Among asymptomatic patients, most of the patients were also Malaysians (73.9\%), of Malay ethnicity $(53.5 \%)$, aged $<40$ years old $(62.0 \%)$, and also from Petaling township (33.1\%). Furthermore, majority of the asymptomatic COVID19 patients were infected through local transmission $(85.9 \%)$ and most of them $(92.3 \%)$ had no comorbidity (Table 1).

Table 1 Characteristics of COVID-19 patients in Petaling District, Selangor, Malaysia.

\begin{tabular}{|c|c|c|c|c|c|c|}
\hline \multirow{3}{*}{ Characteristics } & \multicolumn{6}{|c|}{ COVID-19 patients } \\
\hline & \multicolumn{2}{|c|}{ Symptomatic } & \multicolumn{2}{|c|}{ Asymptomatic } & \multicolumn{2}{|c|}{ Total } \\
\hline & $n$ & $\%$ & $n$ & $\%$ & $n$ & $\%$ \\
\hline \multicolumn{7}{|l|}{ Age group (years) } \\
\hline$<40$ & 136 & 46.6 & 88 & 62.0 & 224 & 51.6 \\
\hline$\geq 40$ & 156 & 53.4 & 54 & 38.0 & 210 & 48.4 \\
\hline \multicolumn{7}{|l|}{ Gender } \\
\hline Male & 146 & 50.0 & 89 & 62.7 & 235 & 54.1 \\
\hline Female & 146 & 50.0 & 53 & 37.3 & 199 & 45.9 \\
\hline \multicolumn{7}{|l|}{ Ethnicity } \\
\hline Malay & 197 & 67.5 & 76 & 53.5 & 273 & 62.9 \\
\hline Non-Malay & 95 & 32.5 & 66 & 46.5 & 161 & 37.1 \\
\hline \multicolumn{7}{|l|}{ Citizenship } \\
\hline Malaysian & 276 & 94.5 & 105 & 73.9 & 381 & 87.8 \\
\hline Non-Malaysian & 16 & 5.5 & 37 & 26.1 & 53 & 12.2 \\
\hline \multicolumn{7}{|l|}{ Transmission } \\
\hline Local & 205 & 70.2 & 122 & 85.9 & 327 & 75.3 \\
\hline Imported cases & 87 & 29.8 & 20 & 14.1 & 107 & 24.7 \\
\hline \multicolumn{7}{|l|}{ Co-morbidity } \\
\hline No & 252 & 86.3 & 131 & 92.3 & 383 & 88.2 \\
\hline Yes & 40 & 13.7 & 11 & 7.7 & 51 & 11.8 \\
\hline \multicolumn{7}{|l|}{ Township } \\
\hline Petaling & 80 & 27.4 & 47 & 33.1 & 127 & 29.3 \\
\hline Sungai Buloh & 97 & 33.2 & 27 & 19.0 & 124 & 28.6 \\
\hline Damansara & 83 & 28.4 & 33 & 23.2 & 116 & 26.7 \\
\hline Bukit Raja & 32 & 11.0 & 34 & 23.9 & 66 & 15.2 \\
\hline \multicolumn{7}{|l|}{ Symptom Status } \\
\hline Fever & 199 & 68.2 & - & - & 199 & 68.2 \\
\hline Cough & 137 & 46.9 & - & - & 137 & 46.9 \\
\hline Sore throat & 76 & 26.0 & - & - & 76 & 26.0 \\
\hline Runny nose & 57 & 19.5 & - & - & 57 & 19.5 \\
\hline Overall & 292 & 67.3 & 142 & 32.7 & 434 & 100.0 \\
\hline
\end{tabular}


The bivariable analysis of independent variables and symptom status of the patients showed a significant association between asymptomatic status with patient's age, gender, ethnicity, citizenship, transmission and township. Asymptomatic cases were mostly among patients aged $<40$ years old (cOR 1.86, 95\% CI 1.24, 2.81), males (cOR 1.67, 95\% CI 1.11, 2.53), non-Malays (cOR 1.80, 95\%CI 1.19, 2.71), non-Malaysians (cOR 6.07, 95\%CI 3.24, 11.39), and local transmission cases (cOR 2.58, 95\%CI 1.51, 4.42). Based on township status, patients from Sungai Buloh (cOR 0.47, 95\%CI 0.27, 0.82) were less likely to be asymptomatic compared to other areas. However, there was no significant association between asymptomatic cases and co-morbidity status. The variables included in the multivariable logistic regression model were age group, gender, ethnicity, citizenship, transmission, co-morbidity and township. After adjusting for confounders, three variables were found to be statistically significant predictors for asymptomatic COVID19 cases. Patients aged $<40$ years old (aOR 1.79, $95 \%$ CI $1.11,2.86$ ) were more likely to be asymptomatic compared with those aged $\geq 40$ years old. COVID-19 patients who were nonMalaysians (aOR 3.22, 95\%CI 1.44, 7.19) and local transmission cases (aOR 2.51, 95\% CI 1.42, 4.42) COVID-19 were more likely to be asymptomatic compared to their respective counterparts. However, there was no significant association between asymptomatic cases and gender, ethnicity, co-morbidity and township (Table 2).

Table 2 Factors associated with asymptomatic COVID-19 patients

\begin{tabular}{|c|c|c|c|c|c|}
\hline \multirow[b]{2}{*}{ Variable } & \multirow[b]{2}{*}{$\mathrm{n}$} & \multicolumn{2}{|c|}{ Simple LR } & \multicolumn{2}{|c|}{ Multiple LR } \\
\hline & & Crude OR $(95 \% \mathrm{CI})$ & $p$ & $\begin{array}{l}\text { Adjusted OR (95\% } \\
\text { CI) }\end{array}$ & $p$ \\
\hline Age group (years) & & & & & $0.015^{*}$ \\
\hline$<40$ & 88 & $1.86(1.24-2.81)$ & $0.003 *$ & $1.79(1.11-2.86)$ & \\
\hline$\geq 40$ & 54 & 1 & & 1 & \\
\hline Gender & & & & & 0.227 \\
\hline Male & 89 & $1.67(1.11-2.53)$ & $0.013^{*}$ & $1.32(0.83-2.10)$ & \\
\hline Female & 53 & 1 & & 1 & \\
\hline Ethnicity & & & & & 0.396 \\
\hline Malay & 76 & 1 & $0.005^{*}$ & 1 & \\
\hline Non-Malay & 66 & $1.80(1.19-2.71)$ & & $1.26(0.73-2.16)$ & \\
\hline Citizenship & & & & & $0.004 *$ \\
\hline Malaysian & 105 & 1 & $0.001^{*}$ & 1 & \\
\hline $\begin{array}{l}\text { Non- } \\
\text { Malaysian }\end{array}$ & 37 & $6.07(3.24-11.39)$ & & $3.22(1.44-7.19)$ & \\
\hline Transmission & & & & & $0.001 *$ \\
\hline Local & 122 & $2.58(1.51-4.42)$ & $0.001 *$ & $2.51(1.42-4.42)$ & \\
\hline $\begin{array}{l}\text { Imported } \\
\text { cases }\end{array}$ & 20 & 1 & & 1 & \\
\hline Co-morbidity & & & & & 0.365 \\
\hline No & 131 & $1.89(0.93-3.80)$ & 0.075 & $1.42(0.66-3.06)$ & \\
\hline Yes & 11 & 1 & & 1 & \\
\hline \multicolumn{6}{|l|}{ Township } \\
\hline Petaling & 47 & 1 & & 1 & \\
\hline Sungai Buloh & 27 & $0.47(0.27-0.82)$ & $0.009 *$ & $0.61(0.33-1.11)$ & 0.107 \\
\hline Damansara & 33 & $0.67(0.39-1.16)$ & 0.157 & $0.91(0.50-1.63)$ & 0.757 \\
\hline Bukit Raja & 34 & $1.80(0.99-3.30)$ & 0.054 & $1.81(0.91-3.59)$ & 0.086 \\
\hline
\end{tabular}

*Significant at $p<0.05$.

\section{DISCUSSION}

WHO has recognized COVID-19 as an infectious disease caused by a newly discovered strain of coronavirus, a type of virus known to cause respiratory infections in humans and has been working closely with the Ministry of Health from the affected countries to control this pandemic. ${ }^{19}$ Due to the novelty of this virus, several challenges are faced in controlling this infection such as the presence of asymptomatic infection which may lead to difficulty in diagnosing and controlling the infection. ${ }^{20}$ Our findings from 434 patients in Petaling District, Selangor, Malaysia revealed that approximately one-third of the patients were asymptomatic and the factors associated with being asymptomatic were younger age group ( $<40$ years), nationality (non-Malaysian) and local transmission cases.

The study revealed that patients of younger age group were more likely to be asymptomatic 
compared to older patients. Our findings coincide with few other studies which also demonstrated a significant association between age and asymptomatic cases. ${ }^{21-23}$ A cross-sectional survey by Mei et al. ${ }^{21}$ reported that the COVID-19 young-age group had a fewer number of symptoms and lower rate of fever than their older counterparts, they did not seem to be susceptible, or their symptoms were relatively mild or no symptoms at all. Similarly, a study among 81 young adults with COVID-19 infection admitted to King Abdullah University Hospital, Jordan revealed that about half of the patients $(n=37,45.7 \%)$ were asymptomatic. ${ }^{22}$ In a systematic review study on asymptomatic COVID19 patients by Kronbichler ${ }^{23}$ revealed that most of the asymptomatic patients were from younger age with the mean age of 31.0 (standard deviation: 23.8) years old. The above studies have shown that asymptomatic patients were more common in young and middle-aged individuals, suggesting that age and the status of health may play an important role in the severity of COVID-19, possibly related to different immune responses to the diseases. ${ }^{12}$ Furthermore, the surface enzyme angiotensinconverting enzyme (ACE2) which has proven to promote internalization of COVID-19 into the human cells was lower in the younger age group compared to adult. $^{24}$

The present findings also revealed that asymptomatic patients were mostly among nonMalaysians. Several studies have described varying degrees of illness (mild, severe, or critical) including of asymptomatic patients may be due to the strain of the COVID-19 virus, features of the population demographic and genetics. ${ }^{25-28}$ In Petaling District, a total of 37 asymptomatic COVID-19 patients were non-Malaysians and approximately $81 \%(n=30)$ of them were from Bangladesh. Thus, the demographic characteristics of the Bangladeshis may play an important role in determining the factors associated with asymptomatic cases in this study. The most possible reason identified was the inherent immunity among Bangladeshis. ${ }^{26}$ Historically, they may experience repeated attacks of respiratory viruses which may keep their immune system primed and has probability of providing some forms of protection from COVID-19 virus. ${ }^{26}$ Another possible reason is the individual genetic variation that may help to explain about different immune responses to a virus in different population and may become more resilient to conditions in those countries compared to other countries. ${ }^{27,28}$ Furthermore, the virus may have mutated when it spreads from China to different part of the continents, which may explain why some COVID19 patients from different countries showed no symptoms compared to other patients in other countries. $^{26}$

In this study, it was noted that the likelihood of being asymptomatic was higher among local transmission cases than the imported cases whom had contracted the disease before returning to the country. The COVID-19 virus originated from China has been mutated to different groups worldwide during the pandemic and initially the virus can be divided into three types: $\mathrm{A}, \mathrm{B}$ and $\mathrm{C}$. The less contagious type B was the most common type in East Asia including in Malaysia, while the more contagious and lethal types $\mathrm{A}$ and $\mathrm{C}$ are normally found in Europeans and Americans. ${ }^{26,29}$ In our study, all asymptomatic COVID-19 patients ( $\mathrm{n}=$ 20) were found to be the citizen of Malaysia. Of these, $45 \%(n=9)$ of them had been to United Kingdom before travelling back to the country while another $20 \%$ of the patients had been to European countries $(n=2)$ and United State of America $(n=$ 2 ). This could be the one of the reason for the local transmission cases in Petaling District were more likely to be asymptomatic compared to the imported cases. In addition, this argument is consistent with the study by Cambridge University and Los Alamos National Laboratory Scientists which reported that the virus has mutated into contagious strain as it left East Asia while traveled to Europe and spreaded in the United States. ${ }^{30}$

This study has some limitations. First, only the COVID-19 confirmed patients resided in Petaling District were included in the study. Patients who were admitted to the hospital in this District, but not a resident of the district of Petaling, were not recorded into the database at the Petaling District Health Office. It would be better to include as many patients as possible from other districts or states to better generalization of the result. Second, the investigation of the patients was conducted through telephone interview by using a standardized investigation form, which is very brief and less informative. In addition, the information obtained from the telephone interview may be subjected to response bias. For instance, it is difficult for the patient to elaborate their responses clearly over phone. Nonetheless, face to face interview is not advisable as the risk of contracting COVID-19 is higher. Lastly, the medical records of the patients who were admitted to the hospital were not available from the database. The strength of the study is that the data collected was considered valid and reliable as the investigations were conducted by trained medical personnel and further verified by a qualified epidemiologist at the Petaling District Health Office.

\section{CONCLUSION}

Approximately one-third of COVID-19 patients in Petaling District were asymptomatic and these patients are easily spreading the virus to others without realizing they are infected. The risk factors identified were younger age, non-Malaysians and local transmission cases. Rigorous epidemiological investigation is helpful in identifying COVID-19 among these groups of people who are 
asymptomatic. Appropriate strategies, such as social distancing, wearing face masks in public, frequent hand washing should be strongly implemented to prevent disease transmission from asymptomatic individuals. Lastly, this study provides a better understanding of various factors that might be contributing to the asymptomatic COVID-19 patients in Petaling District, which serves as baseline findings for future control and research.

\section{ACKNOWLEDGEMENT}

We would like to thank the Director General of Health Malaysia for his permission to publish this article.

Author disclosures

The authors declare that they have no conflicting of interests.

\section{Ethics approval}

Approval to conduct this study was obtained from the Medical Research and Ethics Committee, Ministry of Health Malaysia (NMRR-20-72054598).

\section{REFERENCES}

1. Shigemura J, Ursano RJ, Morganstein JC, Kurosawa M, Benedek DM. Public responses to the novel 2019 coronavirus (2019-nCoV) in Japan: Mental health consequences and target populations. Psychiatry and Clinical Neurosciences. Psychia Clin Neuros. 2020; 74: 277-83.

2. Hussin AR, Siddappa NB. The epidemiology and pathogenesis of coronavirus disease (COVID-19) outbreak. J Autoimmun. 2020; 109: 1024-33.

3. Wang YX, Wang YY, Chen Y, Qin QS. Unique epidemiological and clinical features of the emerging 2019 novel coronavirus pneumonia (COVID-19) implicate special control measures. J Med Virol. 2020; 92: 568-76.

4. World Health Organization. WHO Director-General's Remarks at the Media Briefing on 2019-nCoV on 11 February 2020. 2020. [cited 2020 May 28]. Available from:

https://www.who.int/dg/speeches/detail/w ho-director-general-s-remarks- at-themedia-briefing-on-2019-ncov-on-11february-2020.

5. World Health Organization. Novel Coronavirus (2019-nCoV): Situation Report. [Internet]. 2019 [cited 2020 May 28]. Available from: https://www.who.int/emergencies/diseases /novel-coronavirus-2019/situation-reports.

6. Fairoza Amira H, Cher $\mathrm{Hl}$, Hafeez N, Dominic VL, Guanhua L, Cheng LT, et al.
CoronaTracker: World-wide COVID-19 Outbreak Data Analysis and Prediction. Bull World Health Organ. E-pub: 19 March 2020. [cited 2020 May 28]. Available from: https://www.who.int/bulletin/online_first/2 0-255695.pdf.

7. Nash C. Mediaite. Harvard Professor Sounds Alarm on 'Likely' Coronavirus Pandemic: $40 \%$ to $70 \%$ of World Could Be Infected This Year. 2020 [cited 2020 May 28]. Available from: https:/www.mediaite.com/news/harvardprofessor-sounds-alarm-on-likelycoronavirus-pandemic-40-to-70-of-worldcould-be-infected-this-year/.

8. World Health Organization, WHO Director-General's opening remarks at the media briefing on COVID-19 - 11 March 2020. 2020. [cited 2020 May 28]. Available from:

https://www.who.int/dg/speeches/detail/w ho-director-general-s-opening-remarks-atthe-media-briefing-on-COVID-19---11march-2020.

9. Catrin S, Zaid A, Niamh ON, Mehdi K, Ahmed K, Ahmed AJ, Christos L, et al. World Health Organization declares global emergency: A review of the 2019 novel coronavirus (COVID-19). Int J Surgery. 2020; 76: 71-76.

10. Chen N, Zhou M, Dong X, Qu J, Gong F, Han Y et al., Epidemiological and clinical characteristics of 99 patients of 2019 novel coronavirus pneumonia in Wuhan, China: a descriptive study, Lancet. 2020; 395: 50713.

11. Wu Z, McGoogan JM. Characteristics of and Important Lessons from the Coronavirus Disease 2019 (COVID-19) Outbreak in China: Summary of a Report of 72314 Patients from the Chinese Center for Disease Control and Prevention. J Am Med Assoc. 2020; 323.

12. Graham L. You're only as young as your immune system. New Scientist. 2020. New Scientist Ltd, England. 44-48.

13. Hiroshi N, Tetsuro K, Takeshi M, Ayako S, Sung MJ, Katsuma H. Et al. Estimation of the asymptomatic ratio of novel coronavirus infections (COVID-19). Int J Infec Dis. 2020; 94: 154-55.

14. World Health Organization (WHO). Q\&A on coronaviruses (COVID-19). 2020 [cited 2020 May 26]. Available from: https:/www.who.int/emergencies/diseases /novel-coronavirus-2019/question- andanswers-hub/q-a-detail/q-a-coronaviruses.

15. Kim GU, Kim MJ, Ra SH, Lee J, Bae S, Jung $J$, et al. Clinical characteristics of asymptomatic and symptomatic patients 
with mild COVID-19. Clin Microb Infec. 2020; 26(7): 948.e1-948.e3.

16. Carl H, Jon B, Tom J. COVID-19: What proportion are asymptomatic? Centre for Evidence-Based Medicine, University of Oxford, 2020 [cited 2020 May 28]. Available from https://www.cebm.net/COVID-

19/COVID-19-what-proportion-areasymptomatic/.

17. Kimball A, Hatfield KM, Arons M, James A, Taylor J, Spicer K et al. Asymptomatic and Presymptomatic SARS-CoV-2 Infections in Residents of a Long-Term Care Skilled Nursing Facility — King County, Washington, March 2020. MMWR Morb Mortal Wkly Rep 2020; 69: 377-381.

18. Zhou L, Ruan F, Huang M. SARS-CoV-2 Viral Load in Upper Respiratory Specimens of Infected Patients. N Engl J Med 2020; 382(12): 1177-79.

19. WHO. Coronavirus disease (COVID-19) in Malaysia. 2020 [cited 2020 May 26]. Available from: https://www.who.int/malaysia/emergencie s/coronavirus-disease-(COVID-19)-inMalaysia.

20. Li, Q., Guan, X., Wu, P., Wang, X., Zhou, L., Tong, Y, Feng, Z. Early Transmission Dynamics in Wuhan, China, of Novel Coronavirus-Infected Pneumonia. New Eng J Medic. 2020; 382(13): 1199-1207.

21. Mei X, Zhang Y, Zhu H, Ling Y, Zou Y, Zhang $Z$, et al.Observations about symptomatic and asymptomatic infections of 494 patients with COVID-19 in Shanghai,China. American J Infect Control. 2020. (In press).

22. Samrah SM, Al-Mistarehi AH, Ibnian AM, Raffee LA, Momany SM., Al-Ali M et al. COVID-19 outbreak in Jordan: Epidemiological features, clinical characteristics, and laboratory findings. Annals Medic Surg. 2020; 57: 103-108.
23. Kronbichler A, Kresse D, Yoon S, Lee KH, Effenberger M, Shin JI. Asymptomatic patients as a source of COVID-19 infections:A systematic review and metaanalysis. Int J Infect Diseases. 2020; 98: 180-186.

24. Patel AB, Verma A. Nasal ACE2 Levels and COVID-19 in Children. JAMA. 2020; 323(23): 2386-87.

25. Nadim Mahmud SM. How has Bangladesh remained immune to COVID-19? https://tbsnews.net/thoughts/how-hasbangladesh-remained-immune-COVID19-50419.

26. Forster P, Forster L, Renfrew C, Forster M. Phylogenetic network analysis of SARSCoV-2 genomes. Proc Natl Acad Sci USA. 2020; 117(17): 9241-43.

27. Lanese N. Could genetics explain why some COVID-19 patients worse than others. Life Science. 2020 [cited 2020 May 26]. Available from:https://www.livescience.com/genetic s-could-explain-extreme-covid19-

coronavirus-infections.html.

28. Vijay KJ, Karthikeyan I, Abhishek V, Raju V. Differential mortality in COVID-19 patients from India and western countries. Diabetes \& Metabolic Syndrome: Clin Res Rev. 2020; 14: 1037-41.

29. Liu Y-C, Kuo R-L, Shih S-R. COVID-19: The first documented coronavirus pandemic in history, Biomed J, https://doi.org/10.1016/j.bj.2020.04.007.

30. Achenbach J, Akiko Kashiwagi Chris Mooney. The Washington Post. Researchers ponder why COVID-19 appears deadlier in the U.S. and Europe than in Asia. 2020 [cited 2020 May 26]. Available

from:https://www.washingtonpost.com/wo $\mathrm{rld} /$ researchers-ponder-why-covidappears-more-deadly-in-the-us-andeurope-than-in-asia/2020/05/26/81889d068a9f-11ea-9759-6d20ba0f2c0e_story.html. 